\title{
Applying a Scale for Measuring Store Equity in the Kingdom of Saudi Arabia
}

\author{
Johara Al Assafe ${ }^{1} \&$ Abdullah M. Alhidari ${ }^{2}$ \\ ${ }^{1}$ Doctoral Candidate, Marketing Department, King Saud University, Riyadh, Saudi Arabia \\ ${ }^{2}$ Marketing Department, King Saud University, Riyadh, Saudi Arabia \\ Correspondence: Abdullah M. Alhidari, Marketing Department, King Saud University. P. O. BOX 2454, Riyadh \\ 11451, Saudi Arabia. E-mail: abdullah.alhidari@gmail.com
}

Received: January 8, 2019 Accepted: January 31, 2019 Online Published: February 25, 2019

doi:10.5539/ijms.v11n1p122 URL: https://doi.org/10.5539/ijms.v11n1p122

\begin{abstract}
Store equity is an important source of sustainable competitive advantages for retailers in today's competitive environment. Therefore, retailers should work hard to develop and improve their store equity. Measuring it should constitute the first stage of the development process. The present research provided a scale for measuring store equity in KSA market. It first discusses the store equity construct and then describes procedures for developing and refining a multiple-item measurement scale for the construct. Scale reliability, factor analysis, and validity are then discussed based on an analysis of the data gathered from the Saudi market. The study concludes with a discussion of some potential applications of the scale.
\end{abstract}

Keywords: store equity, store awareness, store image, merchandise, atmosphere, convenience

\section{Introduction}

Over the last two decades, considerable changes have occurred to retailing in most developed countries. These changes include the appearance of new store formats such as retail chains, significant investment in new technology, improvements in logistics, and the emergence of international retail groups. Some of the largest firms are retailers in many countries. For example, Wal-Mart Stores, Inc. is the largest private employer in the US, with a $\$ 117$ billion turnover and 2.3 million employees (Efron, 2017).

This situation also applies to developing and emerging economies. In Saudi Arabia, the retail industry today includes a grocery segment that represents 35 percent of the market; moreover, the growth rate of this market was six percent in 2013. Further, the retail business represents approximately 17 percent of Saudi Arabia's gross domestic product (GDP) (Randheer \& Al-Aali, 2015).

Most retailers are saling the same brands which resulted in a high level of competition among them. Therefore, retailers tried hard to gain a strategic tool with which to differentiate themselves from competitors (Ailawadi \& Keller, 2004). The retailer as a brand is one of the most important tools and is a prominent trend in retailing (Grewal et al., 2004).

The concept of store equity (SE) is new and was derived from the concept of brand equity (BE), with a structure that is parallel to that of BE (Arnett et al., 2003). SE is defined as the "differential effect of store knowledge on customer response to the marketing activities of the store" (Hartman \& Spiro, 2005, p. 1114).

Although several studies have examined SE, their main focus was on (1) SE's antecedents and consequences (e.g., Baldauf et al., 2009; Hartman \& Spiro, 2005; Swoboda et al., 2013) and (2) SE's dimensions, such as store image (hereafter "SI"), store loyalty, and store awareness (e.g., Arnett et al., 2003; Pappu \& Quester, 2006a ; EI Hedhli \& Chebat, 2009). Attempts at measuring SE have been fewer such as Arnett et al. (2003), Pappu and Quester (2006a), and El Hedhli and Chebat (2009)-have focused on developing a scale for measuring SE. However, they did not focus on store image, a major component of SE according to Hartman and Spiro (2005). Moreover, these studies ignored other important dimensions, such as perceived price and assortment. Thus, there is scope for improvement in the store equity measurement methods suggested in this study. This study attempted to apply SE scale in KSA using three dimensions that reflect store awareness and image: merchandise (Price, product quality, and assortment), store atmosphere, and convenience. 


\section{Conceptualization of SE}

The SE concept was derived from the concept of BE (Arnett et al., 2003). The concept of BE started to emerge and capture the attention of scholars such as Aaker (1991) and Keller (1993) who developed the foundation for BE research. Aaker (1991, p. 15) defined BE as "a set of brand assets and liabilities linked to a brand, its name, and symbol, that add to or subtract from the value provided by a product or service to a firm and/or to that firm's customers.", and Keller (1993, p. 2) defined customer based brand equity as "the differential effect that brand knowledge has on consumer response to the marketing of that brand".

Many researchers have built on Aaker's (1991) and Keller's (1993) BE models in order to develop new retailing concepts. For example, based on Aaker's (1991) model, Arnett et al. (2003) introduced the concept of "retailer equity" (hereafter "RE"), and Baldauf et al. (2009) proposed the concept of "retailer-perceived BE, and Londoño et al., (2016) introduced the concept of Consumer-Based Brand-Retailer-Channel Equity (CBBRCE)." Keller's (1993) model was used to develop the SE concept by Hartman and Spiro (2005), "shopper-based mall equity" (hereafter "SBME") by El Hedhli and Chebat (2009), retailer brand equity by Swoboda et al. (2016), and store equity by Saura et al. (2017). In this study, we adopt the SE definition developed by Hartman and Spiro (2005).

\subsection{Review of Existing Store Equity Dimensions}

There has been considerable attention afforded to the dimensions of SE in the literature to date (EI Hedhli and Chebat, 2009; Arnett et al., 2003; Baldauf et al., 2009; Pappu and Quester, 2006a). Extant research suggests that both store awareness and store image are a major component of SE.

\subsubsection{Store Awareness}

Store awareness is the ability of the consumer to recognize or recall a retailer's name or symbol, Pappu and Quester (2006b) defined store awareness as the ability of a consumer to recognize or recall a retailer among a relevant retailer category. If retail builds strong awareness it increases the probability that a retail brand will be included in the consideration set which simplifies the consumer's retail brand choice, making it a habit to choose the retail brand.

\subsubsection{Store Image}

Image construct has been conceptualized as a set of functional and psychological states (Mazursky \& Jacoby, 1986). A functional aspect comprises physical properties such as merchandise selection, price, ranges, and store layout. A psychological aspect comprises emotions such as a sense of belonging and a feeling of friendliness. Hopkins and Alford (2001) added that psychological state includes factors such as atmosphere and convenience, while the functional state includes merchandize, price, services, and personal factors.

Researchers have classified SI dimensions in many ways, but price, assortment, atmosphere, quality, convenience, and customer services have been used by most studies (Mazursky \& Jacoby, 1986; Kasulis \& Lusch, 1981; Samli et al., 1998; Steenkamp \& Wedel, 991; Burt \& Carralero-Encinas, 2000; Ailawadi \& Keller, 2004; El Hedhli \& Chebat, 2009; Swoboda et al., 2016). Our model includes three major dimensions of SI; the store atmosphere, store convenience, and merchandise. These dimensions include both the objective and subjective attributes retailers should consider when formulating marketing strategy (Kasulis \& Lusch, 1981).

Table 1. SE dimensions

\begin{tabular}{|c|c|c|c|c|c|c|c|}
\hline Authors & Source & $\begin{array}{l}\text { Store } \\
\text { awareness }\end{array}$ & $\begin{array}{l}\text { Store } \\
\text { image }\end{array}$ & $\begin{array}{l}\text { Store } \\
\text { loyalty }\end{array}$ & $\begin{array}{l}\text { Store } \\
\text { perceived } \\
\text { quality }\end{array}$ & $\begin{array}{l}\text { Store } \\
\text { associations }\end{array}$ & Context \\
\hline $\begin{array}{l}\text { Hartman and } \\
\text { Spiro (2005) }\end{array}$ & Journal of Business Research & $\sqrt{ }$ & $\sqrt{ }$ & & & & \\
\hline $\begin{array}{l}\text { EI Hedhli and Chebat } \\
(2009)\end{array}$ & Journal of business Research & $\sqrt{ }$ & $\sqrt{ }$ & & & & Canada \\
\hline Arnett et al. (2003) & Journal of Retailing & $\sqrt{ }$ & & $\sqrt{ }$ & $\sqrt{ }$ & $\sqrt{ }$ & US \\
\hline Baldauf et al. (2009) & Journal of Retailing & $\sqrt{ }$ & & $\sqrt{ }$ & $\sqrt{ }$ & $\sqrt{ }$ & Austria \\
\hline $\begin{array}{l}\text { Pappu and Quester } \\
\text { (2006a) }\end{array}$ & $\begin{array}{l}\text { Journal of Retailing and } \\
\text { Consumer Services }\end{array}$ & $\sqrt{ }$ & $\sqrt{ }$ & $\sqrt{ }$ & $\sqrt{ }$ & $\sqrt{ }$ & Austria \\
\hline This Study & & $\sqrt{ }$ & $\sqrt{ }$ & & & & \\
\hline
\end{tabular}




\subsubsection{Merchandise}

Merchandise aspects include three factors related to selling products: assortment, quality, and pricing (Mazursky \& Jacoby, 1986). Assortment has been defined as the "number of different items in a merchandise category" (Broniarczyk et al., 1998, p. 166; McIntyre \& Miller, 1999, p. 296; Broniarczyk, 2008, p. 2).

The price of a product could be viewed from a consumer's perspective as a sacrifice made to obtain that product (Zeithaml, 1988). However, from a behavioral perspective, the price could be perceived as a quality cue (Roa and Monroe, 1988. As a conclusion, the price could be viewed as an indicator of sacrifice, an indicator of quality, or both.

Perceived retailer quality is defined as a "consumer's judgment about a retailer's overall excellence or superiority" (Pappu \& Quester, 2006b, p. 14). According to the Cue utilization theory, products consist of many cues that serve as indicators of quality to shoppers (Richardson et al., 1994). These cues can be classified as extrinsic or intrinsic with regard to the product. Extrinsic cues are product-related attributes such as price, brand name, and packaging, which are not part of the physical product. Conversely, intrinsic cues represent those, such as ingredients, that cannot be manipulated without also altering the physical properties of the product (Richardson et al., 1994; Szybillo \& Jacoby, 1974). In judging product quality, consumers use both intrinsic and extrinsic cues (Kirmani \& Wright, 1989).

\subsubsection{Atmosphere}

Store atmospherics is defined as "the effort to design buying environments to produce specific emotional effects in the buyer that enhance his purchase probability." (Kotler, 1973, p. 50)

Atmosphere consists of color, music, and crowding, lighting, layout, smell, and social features such as the type of clientele, employee availability, and friendliness (Ailawadi \& Keller, 2004). These elements have been categorized into three broad dimensions (Baker et al., 1994; Baker et al., 2002; Lunardo \& Mbengue, 2013): (1) social factors related to people, including store employees and customers; (2) design factors, including layout, color, cleanliness, clutter, and space; and (3) ambient factors, the background conditions in the environment, which include scent, lighting, temperature, music, and noise.

In our model, we specified three main dimensions of store atmosphere: (1) design factors, which include layout, color, and cleanliness; (2) ambient, which includes lighting and music; and (3) social factors, reflecting customer services. Figure 1 depicts the model.

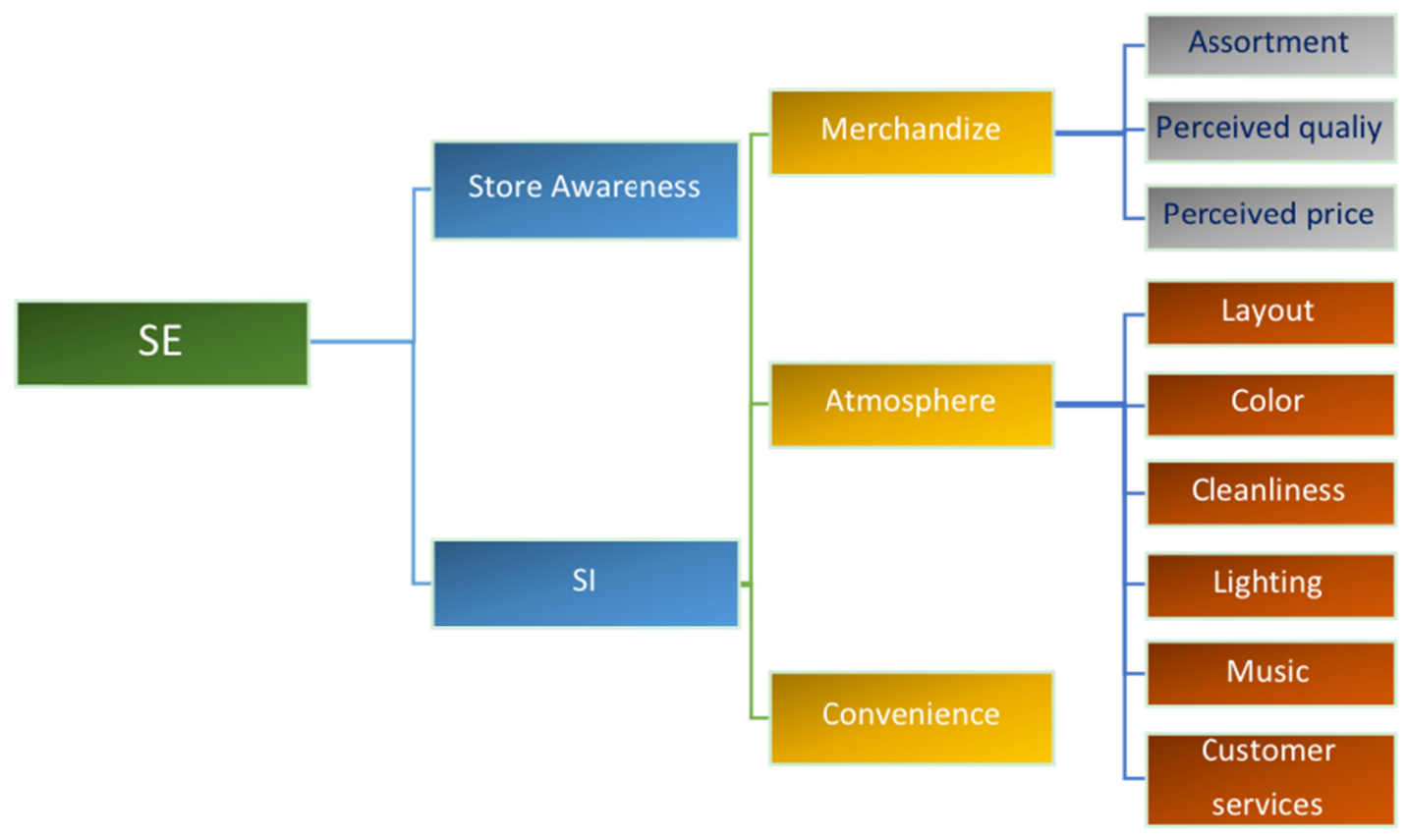

Figure 1. SE dimension 


\subsubsection{Store Convenience}

There are many factors that are related to convenience such as the location of a store, the distance the consumer must travel to shop there, adequate parking, shopping effort, working hours, and quick checkout (Ailawadi and Keller, 2004; Delgado-Ballester et al., 2014; Samli et al., 1998). Moreover, the perceived convenience results from the perceived savings of time and effort during the shoping trip, including the stages of search for a product, evaluation, acquisition, and use convenience (Emrich et al., 2015).

Overall, our model included 11 dimensions of SE: (1) store awareness, (2) assortment, (3) perceived quality, (4) perceived price, (5) convenience, (6) layout, (7) color, (8) cleanliness, (9) lighting, (10) music, and (11) customer services.

\section{Developing a Store Equity Scale}

In the line with prior researches (e.g., Lundstrom \& Lawrence, 1976; Parasuraman et al., 1988; EI Hedhli \& Chebat, 2006; Barkus et al., 2009; Homburg et al., 2015), we followed established scale-development procedures (e.g., Lundstrom \& Lawrence, 1976; Churchill, 1979). The following steps were taken to develop our scale: (1) item generation, (2) scale purification and dimensionality, and (3) reliability and validity assessment. The major focus of this study was to implement this scale in KSA.

\subsection{Scale Item Generation}

The initial items were selected from the study's literature review. These initial 86 items for measuring the SE dimensions are listed in Appendix A. The items were measured using a five-item Likert scale (1= "strongly disagree"; 5 = "strongly agree"; Jenkins \& Taber, 1977; Lissitz \& Green, 1975). After the scale items were generated, the initial item pool was edited to eliminate ambiguous and redundant items. The set of 86 items was submitted to five judges with PhDs in marketing. Statements that did not clearly fit into their category or were considered redundant or ambiguous were eliminated. This review eliminated 16 items; therefore, 70 items remained.

To refine the scale further, the remaining 70 items were sent to 40 experts in research methodology. The data were collected through Amazon's Mechanical Turk, considered an effective data-collection platform (Kees et al., 2017; Smith et al., 2016). This second review produced the same number of items. Therefore, 70 statements were used in the preliminary form of the SE scale.

Initially, we implemented this scale in the US market. Twenty eight items of SE scale captures in a reliable and valid way two main dimensions of SE; awareness and store image, the latter dimension consists of merchandize, atmosphere, and convenience. The scale was internally consistent and reliable.

Table 2. Standardized factor loadings, AVE, and CR (adapted from Amin [2016])

\begin{tabular}{|c|c|c|c|c|}
\hline & Items & $\begin{array}{l}\text { Standardized factor } \\
\text { loading }\end{array}$ & AVE & $\mathrm{CR}$ \\
\hline Music & M2. The store had pleasant music & 0.904 & 0.618 & 0.784 \\
\hline$\alpha=0.815$ & M1. The background music would make shopping in this store pleasant & 0.762 & & \\
\hline Lighting & LT4. This store has appropriate lighting & 0.843 & 0.713 & 0.909 \\
\hline \multirow[t]{3}{*}{$\alpha=0.91$} & LT3. This store has good lighting & 0.838 & & \\
\hline & LT2. Lighting in the store is pleasant & 0.889 & & \\
\hline & LT1. The store is correctly lit & 0.814 & & \\
\hline Layout & AS6. I can find the products I need very easily & 0.86 & 0.682 & 0.870 \\
\hline \multirow[t]{2}{*}{$\alpha=0.878$} & LY4. The store layout makes shopping easy & 0.875 & & \\
\hline & LY3. It was easy to locate products/merchandise in the store & 0.796 & & \\
\hline Customer & CU11. The employees caring about the consumer & 0.768 & 0.523 & 0.882 \\
\hline services & CU10. The employees at this store treat my requests with respect & 0.804 & & \\
\hline \multirow[t]{4}{*}{$\alpha=0.898$} & CU8. Sales people are friendly & 0.758 & & \\
\hline & CU7. Sales people are helpful & 0.787 & & \\
\hline & CU6. Sales people are knowledgeable about their products & 0.75 & & \\
\hline & CU5. The employees at this store are very competent & 0.767 & & \\
\hline Price & P8. This store offers products at favorable prices over a long period. & 0.8 & 0.608 & 0.861 \\
\hline \multirow[t]{3}{*}{$\alpha=0.861$} & P6. The prices at this store are acceptable & 0.792 & & \\
\hline & P3. You get good value for your money & 0.755 & & \\
\hline & P1. The prices at this store are fair & 0.772 & & \\
\hline
\end{tabular}




\begin{tabular}{lllc}
\hline Perceived & PQ5. This store offers very reliable products & 0.846 & 0.584 \\
quality & PQ4. This store offers products of consistent quality & 0.755 & 0.848 \\
$\alpha=0.849$ & PQ2. This store offers a dependable product & 0.735 & \\
& PQ1. The store carries high-quality merchandise & 0.713 & 0.778 \\
\hline Convenience & CV10. The location of this store is easy to reach & 0.913 \\
$\alpha=0.91$ & CV7. This store has a convenient location & 0.906 & 0.836 \\
& CV5. It is easy to get to the store & 0.834 & 0.770 \\
\hline Awareness & AW4. I can quickly recall the logo of this store & 0.919 & 0.870 \\
$\alpha=0.868$ & AW3. I can quickly recall the symbol of this store & & \\
\hline
\end{tabular}

Table 3. Discriminant validity

\begin{tabular}{|c|c|c|c|c|c|c|c|c|}
\hline & Awareness & Convenience & Price & $\begin{array}{l}\text { Perceived } \\
\text { Quality }\end{array}$ & $\begin{array}{l}\text { Customer } \\
\text { Services }\end{array}$ & Music & Lighting & Layout \\
\hline Awareness & 0.878 & & & & & & & \\
\hline Convenience & 0.226 & 0.882 & & & & & & \\
\hline Price & 0.220 & 0.231 & 0.780 & & & & & \\
\hline Perceived Quality & 0.329 & 0.345 & 0.368 & 0.764 & & & & \\
\hline Customer Services & 0.298 & 0.312 & 0.305 & 0.455 & 0.723 & & & \\
\hline Music & 0.214 & 0.224 & 0.219 & 0.327 & 0.380 & 0.786 & & \\
\hline Lighting & 0.260 & 0.272 & 0.266 & 0.397 & 0.461 & 0.332 & 0.844 & \\
\hline Layout & 0.257 & 0.269 & 0.263 & 0.393 & 0.457 & 0.329 & 0.399 & 0.826 \\
\hline \multicolumn{9}{|c|}{ Note: The values in bold are the square root of AVE } \\
\hline
\end{tabular}

\subsection{Scale Purification and Dimensionality}

This stage involved examining the dimensionality of the construct and assessing its reliability. Data were gathered from a sample of 544 adult respondents (18 years of age or older) in KSA. The sample size of 544 meets the requirement of around 20 observations per scale item (Hair et al., 2009). Four KSA department stores were selected for data collection (City Max, Harvey Nichols, Debenhas, and Centerpoint), for two reasons: to include stores that offer both moderate- and high-price items, and to ensure coverage of stores that offer both luxury and trendy products.

Coefficient alpha was used to measure the internal consistency of the set of items (Churchill, 1979; Peter, 1979). The alpha was 0.899, which indicated a high level of internal consistency (Hair et al., 2009; Nunnally, 1978); therefore, no items were deleted from the scale.

The 28 items were subjected to EFA with principal components estimation and Varimax rotation using SPSS 22. A strict loading criterion (0.6) was used to evaluate the Varimax rotated factors (Brakus et al., 2009; El Hehhli \& Chebat, 2009). As a result, 28 items fulfilled the criterion, and eight factors represented distinct dimensions that were easy to interpret: factor 1 (music), factor 2 (lighting), factor 3 (layout), factor 4 (customer services), factor 5 (price), factor 6 (perceived quality), factor 7 (convenience), and factor 8 (awareness).

Hair et al. (2009) provide four criteria for assessing factor loadings: (1) a statistically significant Bartlett's test of sphericity should be significant (Sig. <.05); (2) the measure of sampling adequacy (MSA) values must exceed 0.50 for the overall test; (3) factors should have eigenvalues greater than 1.0; and (4) the communality for each item should be greater than 0.50. The Bartlett's test of sphericity was significant, the MSA was 0.867 , the eigenvalues of each factor were greater than 1 , the communality for each item was above 0.5 , and $76.944 \%$ of the variance was explained by the eight factors. Tables 4 and 5 summarize the factor loading results.

Table 4. KMO and Bartlett's test

\begin{tabular}{lll}
\hline Kaiser-Meyer-Olkin Measure of Sampling Adequacy. & & .867 \\
Bartlett's Test of Sphericity & Approx. Chi-Square & 9519.946 \\
& df & 378 \\
& Sig. & 0.000 \\
\hline
\end{tabular}


Table 5. Summary of results from the first stage of scale purification

\begin{tabular}{|c|c|c|c|c|c|c|}
\hline & Initial & igenvalues & & & & \\
\hline Label & Total & $\begin{array}{l}\% \text { of } \\
\text { Variance }\end{array}$ & $\begin{array}{l}\text { Cumulative } \\
\%\end{array}$ & Items & $\begin{array}{l}\text { Factor loadings of } \\
\text { items on } \\
\text { dimensions to } \\
\text { which they belong }\end{array}$ & communality \\
\hline \multirow{7}{*}{$\begin{array}{l}\text { Customer } \\
\text { Services }\end{array}$} & 8.445 & 30.160 & 30.160 & CU7. Sales people are friendly & .808 & .727 \\
\hline & & & & & & \\
\hline & & & & CU5. The employees at this store are very competent & .758 & .680 \\
\hline & & & & CU11. The employees caring about the consumer & .798 & .709 \\
\hline & & & & $\begin{array}{l}\text { CU10. The employees at this store treat my requests with } \\
\text { respect }\end{array}$ & .830 & .764 \\
\hline & & & & CU8. Sales people are friendly & .806 & .732 \\
\hline & & & & CU6. Sales people are knowledgeable about their products & .728 & .614 \\
\hline \multirow[t]{4}{*}{ Price } & 2.941 & 10.504 & 40.664 & P6. The prices at this store are acceptable & .902 & .844 \\
\hline & & & & $\begin{array}{l}\text { P8. This store offers products at favorable prices over a long } \\
\text { period }\end{array}$ & .825 & .747 \\
\hline & & & & P1. the price at this store are fair & .821 & .737 \\
\hline & & & & P3. you get good value for your money & .802 & .727 \\
\hline \multirow{4}{*}{$\begin{array}{l}\text { perceived } \\
\text { quality }\end{array}$} & 2.255 & 8.052 & 48.716 & PQ4. This store offers products of consistent quality & .844 & .797 \\
\hline & & & & PQ2. This store offers a dependable product & .848 & .823 \\
\hline & & & & PQ1. The store carries high quality merchandise & .755 & .687 \\
\hline & & & & PQ5. This store offers very reliable products & .733 & .686 \\
\hline \multirow[t]{4}{*}{ Lighting } & 1.876 & 6.701 & 55.417 & LT4. this store has appropriate lighting & .847 & .773 \\
\hline & & & & LT3. this store has good lighting & .828 & .724 \\
\hline & & & & LT2. Lighting in the store is pleasant & .758 & .705 \\
\hline & & & & LT1. the store is correctly lit & .716 & .665 \\
\hline \multirow[t]{3}{*}{ convenience } & 1.787 & 6.382 & 61.799 & CV5. It is easy to get to the store & .883 & .861 \\
\hline & & & & CV7. This store has a convenient location & .897 & .893 \\
\hline & & & & CV10. The location of this store is easy to reach & .868 & .834 \\
\hline \multirow[t]{3}{*}{ Layout } & 1.513 & 5.402 & 67.201 & LY3. It was easy to locate products/merchandise in the store & .810 & .811 \\
\hline & & & & LY4. the store layout makes shopping easy & .803 & .788 \\
\hline & & & & AS6. I can find the products I need very easily & .817 & .770 \\
\hline \multirow[t]{2}{*}{ Music } & 1.423 & 5.082 & 72.283 & M2. The store had pleasant music & .919 & .864 \\
\hline & & & & $\begin{array}{l}\text { M1. The background music would make shopping in this } \\
\text { store pleasant }\end{array}$ & .921 & .862 \\
\hline \multirow[t]{2}{*}{ Awareness } & 1.305 & 4.661 & 76.944 & AW3. I can quickly recall the symbol of this store & .907 & .862 \\
\hline & & & & AW4. I can quickly recall the logo of this store & .896 & .858 \\
\hline
\end{tabular}

The next step was to conduct confirmatory factor analyses (CFA). AMOS 21 was used to conduct CFA to specify the pattern by which each measure loaded on a specific factor. The first order was conducted for two dimensions of SI, merchandise, and atmosphere. The result is discussed below.

\subsubsection{Merchandise}

The results show that $\chi^{2}$ was significant $\left(\chi^{2}=103.779, \chi^{2} / \mathrm{df}\right.$ ratio 5.462, $\left.\mathrm{p}=0.00\right)$, the GFI value was 0.956 , the CFI value was 0.966 , and the RMSEA value was 0.091 . Examining the squared multiple correlations for each item revealed that no item had a low $\mathrm{R}^{2}$ values merchandise.

\subsubsection{Atmosphere}

The first-order CFA analysis showed that goodness-of-fit was satisfied, the $\chi^{2}$ was significant $\left(\chi^{2}=270.467\right.$, $\chi^{2} / \mathrm{df}$ ratio $3.22, \mathrm{p}=0.00$ ), the GFI value was 0.936 , the CFI value was 0.959 , and the RMSEA value was 0.064 . Table 6 shows the first- and second-order analyses of atmosphere. 
Table 6. Goodness-of-fit statistics for the measurement model of atmosphere

\begin{tabular}{llllll}
\hline Variable & $\chi^{2} / \mathbf{d f}$ & GFI & CFI & RMSEA & Sig. \\
\hline First-order CFA & 3.22 & 0.936 & 0.959 & 0.064 & 0.00 \\
Second-order CFA & 3.226 & 0.934 & 0.958 & 0.064 & 0.00 \\
\hline
\end{tabular}

After examining the dimensions of SI, the next step was to examine the CFA of SE. Second-Order analysis of the CFA model for the SE results showed that goodness-of-fit was satisfied, the $\chi^{2}$ was significant $\left(\chi^{2}=883.539\right.$, $\chi^{2} / \mathrm{df}$ ratio $2.599, \mathrm{p}=0.00$ ), the GFI value was 0.896 , the CFI value was 0.942 , and the RMSEA value was 0.054 . Therefore, twenty- eight items of the second-order CFA model fit the sample data (see Figure 3).

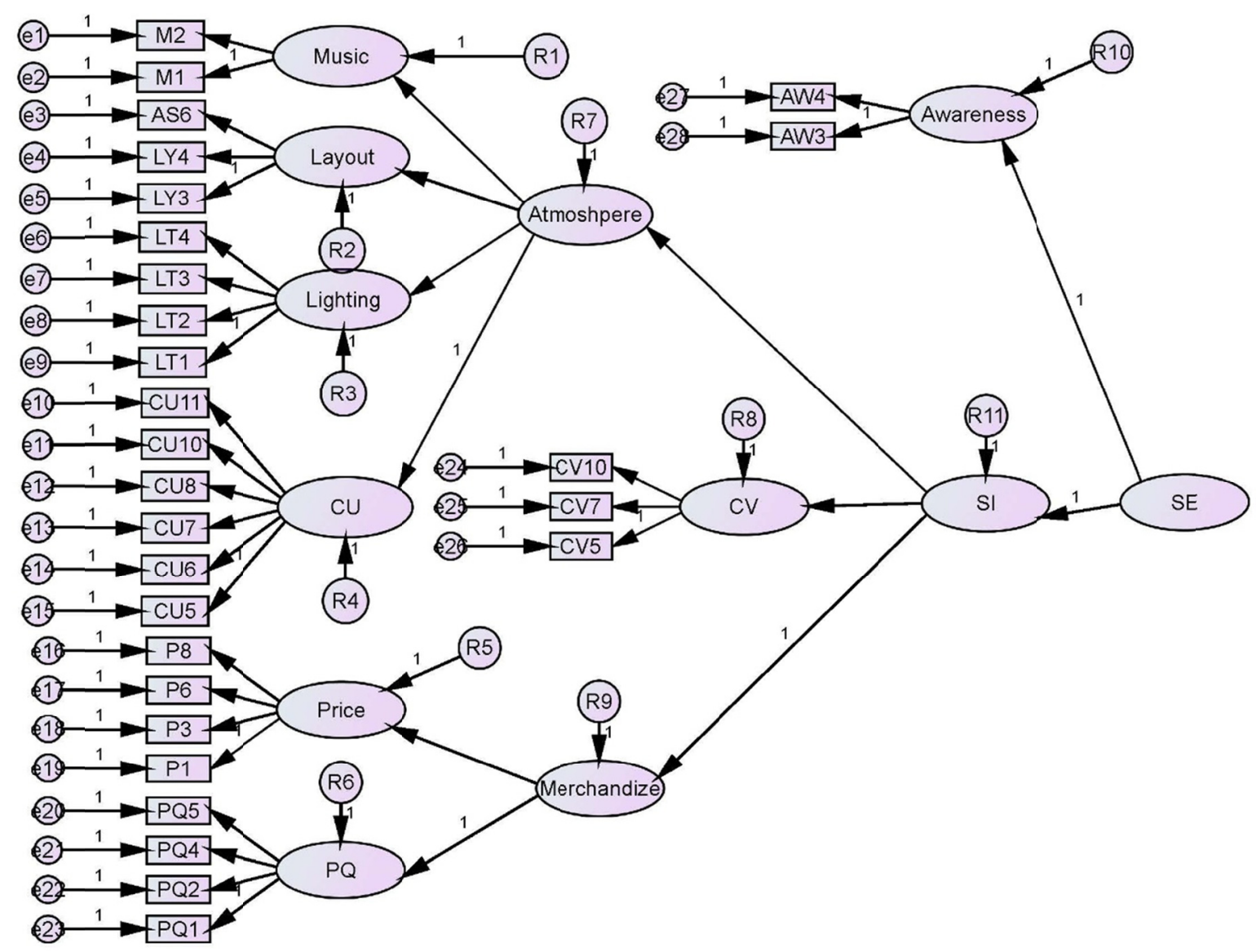

Figure 3. CFA: SE second order

\subsection{Construct Reliability and Validity}

Construct validity was addressed by analyzing construct reliability, convergent validity, and discriminant validity (Peter, 1981). To test reliability, Cronbach's $\alpha$ was computed. It was found to be 0.899 , which indicated a high level of internal consistency (Hair et al., 2009; Nunnally, 1978).

Measuring convergent validity requires three criteria: (1) all the standardized loadings to their respective constructs should be significant and exceed 0.5 (Bagozzi \& Yi, 2012; Hair et al., 2009); (2) the AVE must exceed 0.5 (Bagozzi \& Yi, 1988; Hair et al., 2009); and (3) construct reliability (CR) should exceed 0.7 (Bagozzi \& Yi, 2012; Hair et al., 2009). As Table 7 shows, all factor loadings for each construct were above 0.50 , their AVEs exceeded the recommended thresholds, and their CR exceeded 0.7.

Next, AVE was used to assess the discriminant validity of the construct. Discriminant validity requires that the square root of the AVE between each pair of factors be higher than the correlation estimated between the factors (Bagozzi \& Yi, 1988; Fornell \& Larcker, 1981; Hair et al., 2009). The results in Table 8 show that the square root of the AVE between each pair of factors was higher than the correlation estimated between the factors, demonstrating discriminant validity. 
Table 7. Standardized factor loadings, AVE, CR, and alpha (adapted from Amin [2016])

\begin{tabular}{|c|c|c|c|c|}
\hline & Items & $\begin{array}{l}\text { Standardized } \\
\text { factor loading }\end{array}$ & AVE & $\mathbf{C R}$ \\
\hline \multirow{2}{*}{$\begin{array}{l}\text { Music } \\
\quad=0.841\end{array}$} & M2. The store had pleasant music & 0.961 & 0.751 & 0.856 \\
\hline & M1. The background music would make shopping in this store pleasant & 0.76 & & \\
\hline \multirow{4}{*}{$\begin{array}{l}\text { Lightining } \\
\quad=0.856\end{array}$} & LT4. This store has appropriate lightening & 0.807 & 0.604 & 0.859 \\
\hline & LT3. This store has good lightening & 0.749 & & \\
\hline & LT2. Lighting in the store is pleasant & 0.784 & & \\
\hline & LT1. The store is correctly lit & 0.767 & & \\
\hline \multirow{3}{*}{$\begin{array}{l}\text { Layout } \\
\quad=0.866\end{array}$} & AS6. I can find the products I need very easily & 0.775 & 0.687 & 0.868 \\
\hline & LY4. The store layout makes shopping easy & 0.841 & & \\
\hline & LY3.It was easy to locate products/merchandise in the store & 0.868 & & \\
\hline \multirow{6}{*}{$\begin{array}{l}\text { Customer } \\
\text { services } \\
\quad=0.908\end{array}$} & CU11. The employees caring about the consumer & 0.783 & 0.626 & 0.909 \\
\hline & CU10. The employees at this store treat my requests with respect & 0.86 & & \\
\hline & CU8. Sales people are Friendly & 0.824 & & \\
\hline & CU7. Sales people are Helpful & 0.798 & & \\
\hline & CU6. Sales people are Knowledgeable about their products & 0.714 & & \\
\hline & CU5. The employees at this store are very competent & 0.76 & & \\
\hline \multirow{4}{*}{$\begin{array}{l}\text { Price } \\
\quad=0.888\end{array}$} & P8. This store offers products at favorable prices over a long period. & 0.805 & 0.673 & 0.892 \\
\hline & P6. The prices at this store are acceptable & 0.892 & & \\
\hline & P3. You get good value for your money & 0.777 & & \\
\hline & P1. The prices at this store are fair & 0.804 & & \\
\hline \multirow{4}{*}{$\begin{array}{l}\text { Perceived Quality } \\
\quad=0.88\end{array}$} & PQ5. This store offers very reliable products & 0.744 & 0.656 & 0.883 \\
\hline & PQ4. This store offers products of consistent quality & 0.851 & & \\
\hline & PQ2. This store offers a dependable product & 0.891 & & \\
\hline & PQ1. The store carries high quality merchandise & 0.743 & & \\
\hline \multirow{3}{*}{$\begin{array}{l}\text { Convenience } \\
\quad=0.92\end{array}$} & CV10. The location of this store is easy to reach & 0.85 & 0.795 & 0.921 \\
\hline & CV7. This store has a convenient location & 0.932 & & \\
\hline & CV5. It is easy to get to the store & 0.891 & & \\
\hline & AW4. I can quickly recall the logo of this store & 0.841 & 0.717 & 0.835 \\
\hline \multirow[t]{2}{*}{$=0.834$} & AW3. I can quickly recall the symbol of this store & 0.852 & & \\
\hline & $=0.899$ & & & \\
\hline
\end{tabular}

Table 8. Discriminant validity

\begin{tabular}{|c|c|c|c|c|c|c|c|c|}
\hline & Awareness & Convenience & $\begin{array}{l}\text { Perceived } \\
\text { Quality }\end{array}$ & Price & $\begin{array}{l}\text { Customer } \\
\text { Service }\end{array}$ & Lighting & Layout & Music \\
\hline Awareness & 0.847 & & & & & & & \\
\hline Convenience & 0.192 & 0.892 & & & & & & \\
\hline Perceived Quality & 0.266 & 0.432 & 0.810 & & & & & \\
\hline Price & 0.198 & 0.322 & 0.237 & 0.821 & & & & \\
\hline Customer Service & 0.187 & 0.304 & 0.420 & 0.313 & 0.791 & & & \\
\hline Lighting & 0.180 & 0.291 & 0.403 & 0.300 & 0.460 & 0.777 & & \\
\hline Layout & 0.201 & 0.325 & 0.450 & 0.335 & 0.514 & 0.493 & 0.829 & \\
\hline Music & 0.051 & 0.083 & 0.114 & 0.085 & 0.131 & 0.125 & 0.140 & 0.866 \\
\hline
\end{tabular}

Note. The values in bold are the square root of AVE.

\subsubsection{Nomological Validity}

This step involves testing a well-established theoretical relationship between the measured construct and other constructs (Hair et al., 2009). According to Arnett et al. (2003), Gil-Saura et al. (2016), Gil-Saura et al. (2013), and Fuentes-Blasco et al. (2017) store equity should positively influence shopping intention and customer satisfaction. Consequently, to establish the nomological validity of SE, shopping intention and customer satisfaction were used as the dependent variables, while SE was the independent variable. To measure shopping intention, three items were adapted from Arnett et al. (2003), and four items were adapted from Gelbrich (2011) to measure customer satisfaction.

A structural equation model (SEM) was run using AMOS 21. In line with Arnett et al. (2003), Gil-Saura et al. (2016), Gil-Saura et al. (2013), and Fuentes-Blasco et al. (2017), the SEM results showed that store equity positively influenced shopping intention and customer satisfaction (see Table 19). 
Table 9. Standardized regression for the research model

\begin{tabular}{|c|c|c|c|c|}
\hline Description & Estimate & S.E. & C.R. & $\mathrm{P}$ values \\
\hline Customer Satisfaction <--- SE & 1.5 & 0.105 & 14.28 & 0.000 \\
\hline Shopping Intension <--- SE & 1.44 & 0.105 & 13.715 & 0.000 \\
\hline
\end{tabular}

\section{General Discussion}

\subsection{Theoretical Implications}

This study contributes to SE research by providing a reliable and valid measure of SE using store awareness and store image dimensions (merchandise, store atmosphere, and convenience). Furthermore, It provides a scale that researchers can build on to study

the impact of SE on consumer behavior factors, such as customer satisfaction, customer loyalty, word of mouth, and repatronage intension.

\subsection{Limitation and Future Research Directions}

This study is not without its limitations, one of the limitations was its focus on stores, and one must use caution when applying this scale to other shopping mall types. Therefore, additional research is required to validate the measure by considering different types of shopping malls. Another limitation was the focus on KSA consumers which might limit our ability to fully generalize the findings to other. Future research could examine the applicability of this SE scale to online stores.

\subsection{Managerial Implications}

The scale developed to measure SE should be useful not only in academic research but also in marketing practice. This study's SE scale provide tools that could help marketing managers ways, it can (1) measure current and past performance, (2) serve as a benchmarking tool by which to compare one firm's SE to that of its close rivals, (3) measure the effectiveness of marketing strategies, and (4) examine the relative importance to a retailer of various SE components.

\section{References}

Aaker, D. A. (1991). Managing Brand Equity. New York, NY: The Free Press.

Ailawadi, K. L., \& Keller, K. L. (2004). Understanding retail branding: conceptual insights and research priorities. Journal of Retailing, 80(4), 331-342. https://doi.org/10.1016/j.jretai.2004.10.008

Arnett, D. B., Laverie, D. A., \& Meiers, A. (2003). Developing parsimonious retailer equity indexes using partial least squares analysis: A method and applications. Journal of Retailing, 79(3), 161-170. ttps://doi.org/10.1016/S0022-4359(03)00036-8

Bagozzi, R. P., \& Yi, Y. (2012). Specification, evaluation, and interpretation of structural equation models. Journal of the Academy of Marketing Science, 40(1), 8-34. https://doi.org/10.1007/s11747-011-0278-x

Baker, J., Grewal, D., \& Parasuraman, A. (1994). The influence of store environment on quality inferences and store image. Journal of the Academy of Marketing Science, 22(4), 328-339. https://doi.org/10.1177/0092070394224002

Baker, J., Parasuraman, A., Grewal, D., \& Voss, G. B. (2002). The influence of multiple store environment cues on perceived merchandise value and patronage intentions. Journal of Marketing, 66(2), 120-141. https://doi.org/10.1509/jmkg.66.2.120.18470

Baldauf, A., Cravens, K. S., Diamantopoulos, A., \& Zeugner-Roth, K. P. (2009). The impact of product-country image and marketing efforts on retailer-perceived brand equity: An empirical analysis. Journal of Retailing, 85(4), 437-452. https://doi.org/10.1016/j.jretai.2009.04.004

Bao, Y., Bao, Y., \& Sheng, S. (2011). Motivating purchase of private brands: Effects of store image, product signatureness, and quality variation. Journal of Business Research, 64(2), 220-226. https://doi.org/10.1016/j.jbusres.2010.02.007

Brakus, J. J., Schmitt, B. H., \& Zarantonello, L. (2009). Brand experience: what is it? How is it measured? Does it affect loyalty?. Journal of marketing, 73(3), 52-68. https://doi.org/10.1509/jmkg.73.3.052

Broniarczyk, S. M. (2008). Product assortment. Handbook of Consumer Psychology, 755-779. 
Broniarczyk, S. M., Hoyer, W. D., \& McAlister, L. (1998). Consumers' perceptions of the assortment offered in a grocery category: The impact of item reduction. Journal of Marketing Research, 35, 166-176.

Burt, S., \& Carralero-Encinas, J. (2000). The role of store image in retail internationalization. International Marketing Review, 17(4/5), 433-453. https://doi.org/10.1108/02651330010339941

Churchill Jr, G. A. (1979). A paradigm for developing better measures of marketing constructs. Journal of Marketing Research, XVI, 64-73. https://doi.org/10.1177/002224377901600110

Delgado-Ballester, E., Hernandez-Espallardo, M., \& Rodriguez-Orejuela, A. (2014). Store image influences in consumers' perceptions of store brands: the moderating role of value consciousness. European Journal of Marketing, 48(9/10), 1850-1869. https://doi.org/10.1108/EJM-02-2012-0087

Dodds, W. B., Monroe, K. B., \& Grewal, D. (1991). Effects of price, brand, and store information on buyers' product evaluations. Journal of Marketing Research, 28, 307-319.

Efron, L. (2017). Why Wal-Mart Is Winning In A Losing Industry. Retrieved May 26, 2018, from https://www.forbes.com/sites/louisefron/2017/05/31/why-wal-mart-is-winning-in-a-losing-industry/\#5eadf7 ea44d5

El Hedhli, K., \& Chebat, J. C. (2009). Developing and validating a psychometric shopper-based mall equity measure. Journal of Business Research, 62(6), 581-587. https://doi.org/10.1016/j.jbusres.2008.05.016

Emrich, O., Paul, M., \& Rudolph, T. (2015). Shopping benefits of multichannel assortment integration and the moderating role of retailer type. Journal of Retailing, 91(2), 326-342. https://doi.org/10.1016/j.jretai.2014.12.003

Fornell, C., \& Larcker, D. F. (1981). Evaluating structural equation models with unobservable variables and measurement error. Journal of Marketing Research, 39-50. https://doi.org/10.1177/002224378101800104

Fuentes-Blasco, M., Moliner-Velázquez, B., Servera-Francés, D., \& Gil-Saura, I. (2017). Role of marketing and technological innovation on store equity, satisfaction and word-of-mouth in retailing. Journal of Product and Brand Management, 26(6), 650-666. https://doi.org/10.1108/JPBM-07-2016-1279

Gil-Saura, I., Ruiz Molina, M. E., \& Berenguer-Contri, G. (2016). Store equity and behavioral intentions: the moderating role of the retailer's technology. Journal of Product \& Brand Management, 25(7), 642-650. https://doi.org/10.1108/JPBM-11-2015-1035

Gil-Saura, I., Ruiz-Molina, M. E., Michel, G., \& Corraliza-Zapata, A. (2013). Retail brand equity: a model based on its dimensions and effects. The International Review of Retail, Distribution and Consumer Research, 23(2), 111-136. https://doi.org/10.1080/09593969.2012.746716

Grewal, D., Krishnan, R., Baker, J., \& Borin, N. (1998). The effect of store name, brand name and price discounts on consumers' evaluations and purchase intentions. Journal of Retailing, 74(3), 331-352. https://doi.org/10.1016/S0022-4359(99)80099-2

Grewal, D., Levy, M., \& Lehmann, D. R. (2004). Retail branding and customer loyalty: An overview. Journal of Retailing, 4(80), ix-xii. https://doi.org/10.1016/j.jretai.2004.10.001

Hair, J. F., Anderson, R. E., Babin, B. J., \& Black, W. C. (2009). Multivariate Data Analysis: A Global Perspective (Vol. 7). Upper Saddle River, NJ: Pearson.

Hartman, K. B., \& Spiro, R. L. (2005). Recapturing store image in customer-based store equity: a construct conceptualization. Journal of Business Research, 58(8), 1112-1120. https://doi.org/10.1016/j.jbusres.2004.01.008

Homburg, C., Schwemmle, M., \& Kuehnl, C. (2015). New product design: Concept, measurement, and consequences. Journal of Marketing, 79(3), 41-56. https://doi.org/10.1509/jm.14.0199

Hopkins, C. D., \& Alford, B. L. (2001). A new seven-dimensional approach to measuring the retail image construct. Academy of Marketing Studies Journal, 5(2), 105-114.

Jenkins, G. D., \& Taber, T. D. (1977). A Monte Carlo study of factors affecting three indices of composite scale reliability. Journal of Applied Psychology, 62(4), 392-398. https://doi.org/10.1037/0021-9010.62.4.392

Kasulis, J. J., \& Lusch, R. F. (1981). Validating the retail store image concept. Journal of the Academy of Marketing Science, 9(4), 419-435. https://doi.org/10.1007/BF02729882 
Kees, J., Berry, C., Burton, S., \& Sheehan, K. (2017). An analysis of data quality: Professional panels, student subject pools, and Amazon's Mechanical Turk. Journal of Advertising, 46(1), 141-155. https://doi.org/10.1080/00913367.2016.1269304

Keller, K. L. (1993). Conceptualizing, measuring, and managing customer-based brand equity. The Journal of Marketing, 57, 1-22. https://doi.org/10.1177/002224299305700101

Kirmani, A., \& Wright, P. (1989). Money talks: Perceived advertising expense and expected product quality", Journal of Consumer Research, 16(3), 344-353. https://doi.org/10.1086/209220

Kotler, P. (1973). Atmospherics as a marketing tool. Journal of Retailing, 49(4), 48-64.

Lissitz, R. W., \& Green, S. B. (1975). Effect of the number of scale points on reliability: A Monte Carlo approach. Journal of Applied Psychology, 60(1), 10-13. https://doi.org/10.1037/h0076268

Londoño, J. C., Elms, J., \& Davies, K. (2016). Conceptualising and measuring consumer-based brand-retailerchannel equity. Journal of Retailing and Consumer Services, 29, 70-81. https://doi.org/10.1016/j.jretconser.2015.11.004

Lunardo, R., \& Mbengue, A. (2013). When atmospherics lead to inferences of manipulative intent: Its effects on trust and attitude. Journal of Business Research, 66(7), 823-830. https://doi.org/10.1016/j.jbusres.2011.06.007

Lundstrom, W. J., \& Lamont, L. M. (1976). The development of a scale to measure consumer discontent. Journal of Marketing Research, 13, 373-381. https://doi.org/10.1177/002224377601300407

Mazursky, D., \& Jacoby, J. (1986). Exploring the development of store images. Journal of Retailing, 62(2), 145 165.

McIntyre, S. H., \& Miller, C. M. (1999). The selection and pricing of retail assortments: An empirical approach. Journal of Retailing, 75(3), 295-318. https://doi.org/10.1016/S0022-4359(99)00010-X

Nunnally, J. C. (1978). Psychometric theory (2nd ed.). NY: McGraw-Hill.

Pappu, R., \& Quester, P. (2006a). A consumer-based method for retailer equity measurement: Results of an empirical study. Journal of Retailing and Consumer Services, 13(5), 317-329. https://doi.org/10.1016/j.jretconser.2005.10.002

Pappu, R., \& Quester, P. (2006b). Does customer satisfaction lead to improved brand equity? An empirical examination of two categories of retail brands. Journal of Product \& Brand Management, 15(1), 4-14. https://doi.org/10.1108/10610420610650837

Parasuraman, A., Zeithaml, V. A., \& Berry, L. L. (1988). Servqual: A multiple-item scale for measuring consumer perception of service quality. Journal of Retailing, 64(1), 12-37.

Peter, J. P. (1979). Reliability: A review of psychometric basics and recent marketing practices. Journal of Marketing Research, 16, 6-17. https://doi.org/10.1177/002224377901600102

Peter, J. P. (1981). Construct validity: A review of basic issues and marketing practices. Journal of Marketing Research, 18, 133-145. https://doi.org/10.1177/002224378101800201

Richardson, P. S., Dick, A. S., \& Jain, A. K. (1994). Extrinsic and intrinsic cue effects on perceptions of store brand quality. The Journal of Marketing, 58, 28-36. https://doi.org/10.1177/002224299405800403

Samli, A. C., Kelly, J. P., \& Hunt, H. K. (1998). Improving the retail performance by contrasting management-and customer-perceived store images: A diagnostic tool for corrective action. Journal of Business Research, 43(1), 27-38. https://doi.org/10.1016/S0148-2963(98)00008-3

Saura, I. G., Berenguer-Contrí, G., Molina, M. E. R., \& Michel, G. (2017). Customer segmentation based on store equity: What explains customer store preference?. Journal of Brand Management, 24(6), 546-561. https://doi.org/10.1057/s41262-017-0049-1

Smith, S. M., Roster, C. A., Golden, L. L., \& Albaum, G. S. (2016). A multi-group analysis of online survey respondent data quality: Comparing a regular USA consumer panel to MTurk samples. Journal of Business Research, 69(8), 3139-3148. https://doi.org/10.1016/j.jbusres.2015.12.002

Steenkamp, J. B. E., \& Wedel, M. (1991). Segmenting retail markets on store image using a consumer-based methodology. Journal of Retailing, 67(3), 300-320. 
Swoboda, B., Berg, B., \& Schramm-Klein, H. (2013). Reciprocal effects of the corporate reputation and store equity of retailers. Journal of Retailing, 89(4), 447-459. https://doi.org/10.1016/j.jretai.2013.06.006

Swoboda, B., Weindel, J., \& Hälsig, F. (2016). Predictors and effects of retail brand equity-A cross-sectoral analysis. Journal of Retailing and Consumer Services, 31, 265-276. https://doi.org/10.1016/j.jretconser.2016.04.007

Szybillo, G. J., \& Jacoby, J. (1974). Intrinsic versus extrinsic cues as determinants of perceived product quality. Journal of Applied Psychology, 59(1), 74-78. https://doi.org/10.1037/h0035796

Theodoridis, P. K., \& Chatzipanagiotou, K. C. (2009). Store image attributes and customer satisfaction across different customer profiles within the supermarket sector in Greece. European Journal of Marketing, 43(5/6), 708-734. https://doi.org/10.1108/03090560910947016

US Census Bureau. E-Stats 2015: Measuring the Electronic Economy. Retrieved from https://www.census.gov/library/publications/2017/econ/2015-e-stats.html

Yoo, C., Park, J., \& MacInnis, D. J. (1998). Effects of store characteristics and in-store emotional experiences on store attitude. Journal of Business Research, 42(3), 253-263. https://doi.org/10.1016/S0148-2963(97)00122-7

Zeithaml, V. A. (1988). Consumer perceptions of price, quality, and value: a means-end model and synthesis of evidence. The Journal of Marketing, 52, 2-22. https://doi.org/10.1177/002224298805200302

\section{Copyrights}

Copyright for this article is retained by the author, with first publication rights granted to the journal.

This is an open-access article distributed under the terms and conditions of the Creative Commons Attribution license (http://creativecommons.org/licenses/by/4.0/). 